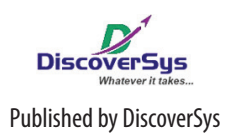

Published by DiscoverSys

\section{Disease History and Delayed Diagnosis of Dengue Infection as Risk Factors for Dengue Shock Syndrome in Wangaya Hospital Denpasar}

\author{
I Made Suganda Yatra, ${ }^{1,3^{*}}$ I Wayan Gede Artawan Eka Putra, ${ }^{2,3}$ \\ Gede Ngurah Indraguna Pinatih ${ }^{3,4}$
}

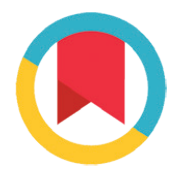

CrossMark

\section{ABSTRACT}

Background and purpose: Dengue Haemorrhagic Fever (DHF) is a serious public health concern in Bali Province, especially in Denpasar wherein the incidence rate amounted to 217.7 per 100,000 in 2014. This figure is much higher than national incidence of 51 per 100,000. Dengue Shock Syndrome (DSS) frequently occur alongside high mortality. This research aims to identify risk factors of DSS among DHF patients hospitalized in Wangaya Hospital Denpasar.

Methods: A case-control study was conducted. Cases (47) were DSS patients and controls (94) were dengue patients hospitalized in Wangaya Hospital in 2013- 2014. Data were collected from medical records on as age, gender, duration of fever, dengue history, haematocrit, platelets, class of care and health insurance.
Results: Risk factors that independently associated with DSS were history of previous dengue infection with adjusted $0 R=11.6$ $(95 \% \mathrm{Cl}=1.83-73.96)$, duration of fever before admission $\geq 4$ days with adjusted $O R=5.5(95 \% \mathrm{Cl}: 2.03-14.96)$, haematocrit $\geq 42 \%$ with adjusted $\mathrm{OR}=2.8$ (95\%Cl: $1.02-7.68)$, platelets $<50,000 / \mathrm{mm} 3$ with adjusted $O R=5.2$ (95\%Cl: 1.88-14.36), and third class ward with adjusted $\mathrm{OR}=2.9(95 \% \mathrm{Cl}: 1.01-8.29)$.

Conclusion: History of previous dengue infection and delay in recognizing the symptoms of dengue fever increased risk of DSS. In addition, patients who hospitalized in the third class ward had higher risk of DSS.

\title{
Riwayat Demam Dengue dan Keterlambatan Diagnosis sebagai Faktor Risiko Dengue Shock Syndrome di RSUD Wangaya Denpasar
}

\section{ABSTRAK}

Latar belakang dan tujuan: Demam Berdarah Dengue (DBD) merupakan masalah kesehatan masyarakat di Provinsi Bali terutama di Kota Denpasar dengan angka insiden tahun 2014 sebesar 217,7/100.000 penduduk. Angka tersebut jauh lebih tinggi dari angka insiden nasional

'Denpasar Health Office, ${ }^{2} S$ chool of Public Health Faculty of Medicine Udayana University, ${ }^{3}$ Public Health Postgraduate Program Udayana University, ${ }^{4}$ Department of Community and Preventive Medicine Faculty of Medicine Udayana University

*Correspondence to: I Made Suganda Yatra, I Made Suganda Yatra, Public Health Postgraduate Program Udayana University

sugandayatra7@gmail.com dari rekam medik yaitu umur, jenis kelamin, lama demam, riwayat DBD, hematokrit, trombosit, kelas perawatan dan jaminan kesehatan. Hasil: Faktor yang secara independen terbukti berhubungan dengan kejadian DSS adalah riwayat infeksi DBD dengan adjusted $\mathrm{OR}=11,6$ $(95 \% \mathrm{Cl}=1,83-73,96)$, lama demam sebelum masuk rumah sakit $\geq 4$ hari dengan adjusted $\mathrm{OR}=5,5(95 \% \mathrm{Cl}: 2,03-14,96)$, hematokrit $\geq 42 \%$ dengan adjusted $0 \mathrm{R}=2,8(95 \% \mathrm{Cl}: 1,02-7,68)$, trombosit $<50.000 / \mathrm{mm}^{3}$ dengan adjusted $\mathrm{OR}=5,2(95 \% \mathrm{Cl}: 1,88-14,36)$ dan perawatan di Kelas III dengan adjusted $0 \mathrm{R}=2,9$ (95\% Cl: 1,01-8,29). Simpulan: Riwayat infeksi DBD sebelumnya dan keterlambatan mengenali gejala DBD meningkatkan risiko terjadinya DSS. Selain itu kelas perawatan juga meningkatkan risiko terjadinya DSS. 


\section{PENDAHULUAN}

Demam Berdarah Dengue (DBD) sering ditemukan di daerah tropis dan sub-tropis termasuk di Indonesia dan penyebarannya dijumpai semakin meningkat. Perjalanan penyakitnya relatif cepat dan berpotensi menyebabkan kematian. ${ }^{1}$ Provinsi Bali pada tahun 2014 merupakan daerah dengan angka insiden DBD tertinggi di Indonesia sebesar 204,22/100.000 penduduk, ${ }^{2}$ dan Kota Denpasar menempati urutan pertama di Provinsi Bali dengan insiden pada tahun 2014 sebesar 217,7/100.000 penduduk. ${ }^{3}$ Angka tersebut jauh lebih tinggi dari angka insiden nasional sebesar 51/100.000 penduduk. $^{4}$

Manifestasi klinis DBD sangat bervariasi, patogenitas yang kompleks dan adanya serotipe virus yang berbeda pada daerah yang berbeda, menyulitkan dalam memprediksi perjalanan penyakit DBD dan menilai terjadinya DSS. ${ }^{4}$ Beberapa penelitian telah dilakukan terkait faktor risiko kejadian DSS di rumah sakit dengan hasil yang berbeda-beda karena adanya perbedaan pada fokus penelitian, perbedaan karakteristik sampel, kriteria inklusi dan eksklusi, perbedaan jumlah dan jenis variabel.

Penelitian di Bali tentang faktor risiko kejadian DSS masih jarang dilakukan. Penelitian di RSUP Sanglah, dengan mengambil rekam medik di Bagian Anak, menemukan hanya status gizi yang mempengaruhi kejadian DSS, sedangkan umur, jenis kelamin dan jenis infeksi tidak berpengaruh. ${ }^{5}$ Hasil penelitian tersebut tidak konsisten dengan penelitian lain. ${ }^{6,7,8}$ Penelitian lain di RSUP Sanglah hanya menghubungkan jumlah leukosit, trombosit, dan kadar hematokrit terhadap terjadinya perdarahan masif pada pasien DSS. ${ }^{9}$

Terbatasnya informasi terkait faktor sosial pada pasien DBD dapat menyebabkan penanggulangan pasien DSS dan perencanaan program kesehatan dalam bidang pencegahan DSS menjadi kurang tepat, sehingga diperlukan penelitian terkait faktor risiko klinis dan sosial DSS. Penelitian ini dilaksanakan di RSUD Wangaya Denpasar yang merupakan rumah sakit pemerintah Kelas B dan menjadi salah satu rumah sakit rujukan untuk Kota Denpasar dan sekitarnya.

\section{METODE}

Penelitian ini bersifat observasional dengan rancangan kasus kontrol yang dilakukan pada Bulan Maret sampai April 2015 di RSUD Wangaya Denpasar. Kasus adalah pasien yang didiagnosis DSS bertempat tinggal di Kota Denpasar dan berdasarkan hasil konfirmasi laboratorium oleh dokter rumah sakit yang merawat. Kontrol adalah semua pasien DBD bertempat tinggal di Kota Denpasar yang dirawat inap namun tidak mengalami kejadian DSS. Kontrol diupayakan mempunyai karakteristik yang sama dengan kasus dalam hal tempat tinggal (kecamatan di Kota Denpasar). Sampel kasus dan kontrol diambil dari data rekam medik pasien yang dirawat inap di RSUD Wangaya selama tahun 2013-2014 dan mempertimbangkan kemungkinan ada data missing pada variabel-variabel yang diteliti.

Jumlah sampel sebanyak 141 pasien yang terdiri dari 47 kasus dan 94 kontrol dengan rasio kasus dan kontrol 1:2. Kontrol dipilih secara acak sistematik, yang berasal dari kecamatan yang sama dengan kasus. Kriteria inklusi meliputi penderita beralamat di Kota Denpasar. Pasien dieksklusi apabila data pasien tidak memiliki hasil konfirmasi laboratorium, dan memiliki penyakit penyerta.

Variabel yang diukur adalah kejadian DSS sebagai variabel tergantung, sedangkan umur, jenis kelamin, lama demam sebelum masuk rumah sakit (MRS), riwayat infeksi DBD sebelumnya, hematokrit MRS, trombosit MRS, kelas perawatan, jaminan kesehatan sebagai variabel bebas.

Analisis data menggunakan program STATA SE 12.1 secara bivariat dan multivariat menggunakan regresi logistik. Penelitian ini mendapat kelaikan etik dari Komisi Etik Fakultas Kedokteran Universitas Udayana/Rumah Sakit Umum Pusat Sanglah Denpasar.

\section{HASIL}

Pada Tabel 1 terlihat bahwa tidak ada perbedaan yang bermakna pada kelompok kasus dan kontrol berdasarkan umur dan jenis kelamin. Hampir setengah dari kasus maupun kontrol (46,8\%) bertempat tinggal di Kecamatan Denpasar Barat.

Pada Tabel 1 disajikan crude odd ratio masingmasing faktor risiko yang diteliti, dimana faktor risiko yang secara statistik meningkatkan kejadian DSS adalah lama demam sebelum MRS $\geq 4$ hari (crude $\mathrm{OR}=8,2$ ), riwayat infeksi $\mathrm{DBD}$ (crude $\mathrm{OR}=8,1$ ), hematokrit $\mathrm{MRS} \geq 42 \%$ (crude $\mathrm{OR}=3,5$ ), trombosit MRS $<50.000 / \mathrm{mm}^{3}$ (crude OR=9,2), perawatan pada Kelas III (crude $\mathrm{OR}=2,6$ ) dan variabel jaminan kesehatan daerah atau JKBM (crude OR=5,3).

Variabel-variabel dengan nilai $\mathrm{p}<0,25$ dimasukkan dalam model analisis multivariat. Sebelum itu dilakukan uji korelasi terlebih dahulu untuk mengukur kekuatan dan arah hubungan antar variabel independen. Diperoleh bahwa hubungan antara perawatan Kelas III dan adanya jaminan kesehatan dari pemerintah didapatkan sebesar 0,7 $(\mathrm{p}=0,001)$. Karena kedua variabel ini mempunyai hubungan yang kuat maka yang dipilih 
Tabel 1 Crude OR faktor risiko DSS pada penderita DBD yang dirawat inap di RSUD Wangaya Kota Denpasar Tahun 2013-2014

\begin{tabular}{|c|c|c|c|c|c|}
\hline Karakteristik & $\begin{array}{l}\text { DBD } \\
\text { n (\%) }\end{array}$ & $\begin{array}{c}\text { DSS } \\
\text { n (\%) }\end{array}$ & Crude OR & $95 \% \mathrm{Cl}$ & Nilai p \\
\hline \multicolumn{6}{|l|}{ Umur } \\
\hline$\geq 15$ tahun & $68(72,3)$ & $26(55,3)$ & & & \\
\hline$<15$ tahun & $26(27,7)$ & $21(44,7)$ & 2,1 & $0,95-4,67$ & 0,043 \\
\hline \multicolumn{6}{|l|}{ Jenis kelamin } \\
\hline Perempuan & $41(43,6)$ & $21(44,7)$ & & & \\
\hline Laki-laki & $53(56,4)$ & $26(55,3)$ & 0,9 & $0,45-2,06$ & 0,904 \\
\hline \multicolumn{6}{|c|}{ Lama demam sebelum MRS } \\
\hline$<4$ hari & $62(66,0)$ & $9(19,1)$ & & & \\
\hline$\geq 4$ hari & $32(34,0)$ & $38(80,9)$ & 8,2 & $3,32-21,38$ & 0,001 \\
\hline \multicolumn{6}{|c|}{ Riwayat infeksi DBD } \\
\hline Tidak Pernah & $92(97,9)$ & $40(85,1)$ & & & \\
\hline Pernah & $2(2,1)$ & $7(14,9)$ & 8,1 & $1,42-81,41$ & 0,003 \\
\hline \multicolumn{6}{|l|}{ Hematokrit MRS } \\
\hline$<42 \%$ & $54(57,4)$ & $13(27,7)$ & & & \\
\hline$\geq 42 \%$ & $40(42,6)$ & $34(72,3)$ & 3,5 & $1,56-8,21$ & 0,001 \\
\hline \multicolumn{6}{|l|}{ Trombosit MRS } \\
\hline$\geq 50.000 / \mathrm{mm}^{3}$ & $81(86,2)$ & $19(40,4)$ & & & \\
\hline$<50.000 / \mathrm{mm}^{3}$ & $13(13,8)$ & $28(59,6)$ & 9,2 & $3,73-22,9$ & 0,001 \\
\hline \multicolumn{6}{|l|}{ Kelas perawatan } \\
\hline Non kelas III & $73(77,7)$ & $27(57,4)$ & & & \\
\hline Kelas III & $21(22,3)$ & $20(42,6)$ & 2,6 & $1,12-5,85$ & 0,013 \\
\hline \multicolumn{6}{|c|}{ Jaminan kesehatan } \\
\hline Non JKBM & $75(79,8)$ & $20(42,5)$ & & & \\
\hline JKBM & $19(20,2)$ & $27(57,5)$ & 5,3 & $2,31-12,33$ & 0,001 \\
\hline
\end{tabular}

Tabel 2 Adjusted OR faktor risiko DSS pada penderita DBD yang dirawat inap di RSUD Wangaya Kota Denpasar Tahun 2013-2014

\begin{tabular}{lcccc}
\hline & & \multicolumn{2}{c}{$\mathbf{9 5 \% C l}$} & Nilai p \\
\cline { 3 - 4 } Variabel & Adjusted OR & Lower & Upper & Nilan \\
\hline Umur $<15$ tahun & 2,5 & 0,94 & 6,88 & 0,067 \\
Lama demam sebelum MRS $\geq 4$ hari & 5,5 & 2,03 & 14,96 & 0,001 \\
Riwayat infeksi DBD sebelumnya & 11,6 & 1,83 & 73,96 & 0,009 \\
Hematokrit MRS $\geq 42 \%$ & 2,8 & 1,02 & 7,68 & 0,001 \\
Trombosit MRS $<50.000 / \mathrm{mm}^{3}$ & 5,2 & 1,88 & 14,36 & 0,001 \\
Perawatan kelas III & 2,9 & 1,01 & 8,29 & 0,049
\end{tabular}

untuk diikutkan dalam model dalam analisis multivariat adalah variabel perawatan Kelas III.

Pada Tabel 2 disajikan hasil analisis multivariat dengan metode regresi logistik. Faktor risiko yang secara independen berhubungan dengan kejadian DSS yaitu lama demam sebelum MRS $\geq 4$ hari dengan adjusted OR sebesar 5,5 (95\%CI:2,03$14,96)$, riwayat infeksi DBD sebelumnya dengan adjusted OR sebesar 11,6 (95\%CI: 1,83-73,96), hematokrit MRS $\geq 42 \%$ dengan adjusted OR sebesar 2,8 (95\%CI: 1,02-7,68), trombosit MRS $<50.000 / \mathrm{mm}^{3}$ dengan adjusted OR sebesar 5,2 (95\%CI: 1,88-14,36) dan perawatan Kelas III dengan adjusted OR sebesar 2,9 (95\%CI: 1,018,29 ). Faktor risiko perawatan Kelas III mempunyai nilai batas bawah 95\%CI sebesar 1,01 atau hampir mendekati 1, yang berarti bahwa variabel ini mempunyai manfaat praktis yang tidak signifikan. 


\section{DISKUSI}

Dalam penelitian ini lama demam $\geq 4$ hari sebelum MRS dijumpai sebagai faktor risiko yang bermakna terhadap terjadinya DSS, dimana lama demam $\geq 4$ hari sebelum MRS meningkatkan risiko terjadinya DSS pada penderita DBD sebesar 5,5 kali. Penelitian lain melaporkan bahwa fase syok terjadi pada hari ketiga sampai hari kelima. ${ }^{6,10}$ Masa kritis penyakit DBD adalah pada saat terjadinya penurunan suhu badan, munculnya trombositopenia dengan disertai hemokonsentrasi yang mencerminkan kebocoran plasma. ${ }^{1,11}$ Penggantian cairan yang tepat dan segera dengan pemberian larutan isotonik plasma adalah tindakan yang dapat menghindarkan terjadinya syok. ${ }^{4,11}$

Dalam penelitian ini riwayat infeksi dengue sebelumnya merupakan faktor yang secara bermakna meningkatkan risiko terhadap kejadian DSS sebesar 11,6 kali dan temuan ini konsisten dengan hasil penelitian lainnya bahwa infeksi dengue sebelumnya merupakan variabel yang dapat mempengaruhi kejadian DSS., ${ }^{712}$

Secara patogenesis yang dapat menjelaskan hal ini adalah faktor virus serta respons imun cell-mediated. Penderita yang sembuh dari infeksi dengan satu jenis serotipe virus akan memberikan imunitas seumur hidup, tetapi tidak memberikan perlindungan terhadap infeksi serotipe virus dengue lain. ${ }^{1,11,13}$ Infeksi kedua oleh virus dengue dengan serotipe yang berbeda akan menyebabkan keadaan penderita menjadi parah karena terjadi antibodi non netralisasi yang memiliki sifat memacu replikasi virus. ${ }^{1}$

Dalam penelitian ini hematokrit pada saat masuk rumah sakit $\geq 42 \%$ secara bermakna meningkatkan risiko DSS sebesar 2,8 kali. Temuan ini sesuai dengan hasil penelitian lainnya yang menyatakan bahwa hematokrit berhubungan dengan kejadian DSS. ${ }^{6,8,14,16}$ Pada pasien DBD dengan perdarahan dan hemokonsentrasi akan mengalami tanda syok lebih dini, tetapi dengan manajemen cairan yang tepat dan adekuat akan dapat mencegah perkembangan ke arah syok. ${ }^{11,15}$

Dalam penelitian ini dijumpai bahwa nilai trombosit $<50.000 / \mathrm{mm}^{3}$ ketika pasien masuk rumah sakit memiliki risiko sebesar 5,2 kali untuk menjadi DSS. Hal ini dijumpai juga pada penelitian lainnya. ${ }^{6,10,16}$ Secara patologis nilai trombosit yang rendah akan berpengaruh pada sistem koagulasi dan mempunyai peranan sebagai penyebab perdarahan pada penderita DBD. Trombositopenia dapat mulai tampak pada penderita DBD beberapa hari setelah demam dan mencapai nilai terendah pada saat mengalami syok. Pemeriksaan perlu diulang setiap 4-6 jam sampai terbukti bahwa jumlah trombosit dalam batas normal atau keadaan klinis penderita sudah membaik.,11

Perawatan Kelas III secara bermakna dijumpai meningkatkan risiko kejadian DSS pada penderita DBD dengan OR sebesar 2,9. Hasil ini menunjukkan bahwa perawatan Kelas III secara tidak langsung menggambarkan ekonomi pasien yang kemungkinan berhubungan dengan keterlambatan pasien untuk mencari pengobatan di rumah sakit. ${ }^{17}$

Implikasi dari hasil penelitian ini adalah perlunya edukasi kepada masyarakat untuk meningkatkan kewaspadaan dini terhadap kemungkinan terjadinya DBD pada pasien yang demam. Selain itu diagnosa dan pengobatan yang cepat dan tepat ketika pasien masuk rumah sakit akan bisa mengurangi terjadinya kematian pada pasien DBD.

Keterbatasan dalam penelitian ini adalah penggunaan rekam medik untuk meneliti faktor risiko DSS sehingga variabelnya sangat terbatas pada informasi yang tersedia di rekam medik. Faktor risiko lainnya, misalnya status gizi dan serotipe virus yang kemungkinan menjadi faktor risiko DSS tidak bisa diteliti karena tidak tersedia di rekam medik. Selain itu, validasi data yang ada di rekam medik tidak bisa dilakukan, misalnya informasi tentang riwayat infeksi DBD sebelumnya dan lama demam sebelum MRS. Kesalahan terhadap data tersebut dapat mengakibatkan estimasi besar OR yang lebih tinggi atau lebih rendah.

\section{SIMPULAN}

Riwayat infeksi DBD sebelumnya dan keterlambatan mengenali gejala DBD meningkatkan risiko terjadinya DSS. Selain itu kelas perawatan juga meningkatkan risiko terjadinya DSS.

\section{UCAPAN TERIMA KASIH}

Ucapan terima kasih penulis sampaikan kepada Direktur Utama RSUD Wangaya Denpasar yang telah memberikan ijin penelitian. Ucapan terima kasih juga disampaikan kepada petugas surveilan dan petugas rekam medik yang telah membantu dalam proses pelaksanaan penelitian ini.

\section{DAFTAR PUSTAKA}

1. Kementerian Kesehatan RI. Modul Pengendalian Demam Berdarah Dengue. Jakarta: Kementerian Kesehatan RI; 2011.

2. Kementerian Kesehatan RI. Profil Kesehatan Indonesia. Jakarta: Kementerian Kesehatan RI; 2015.

3. Dinas Kesehatan Provinsi Bali. Laporan Program P2 DBD. Bali: Dinas Kesehatan Provinsi Bali; 2014. 
4. Kementerian Kesehatan RI. Pedoman Pengendaliann DBD di Indonesia. Jakarta: Kementerian Kesehatan RI; 2013.

5. Elmy. Obesitas sebagai Faktor Risiko Sindrom Syok Dengue, 2009; 11(4), 238-243.

6. Harisnal. Faktor-faktor Risiko Kejadian Dengue Shock Syndrome pada Pasien Demam Berdarah Dengue di RSUD Ulin dan RSUD Ansari Saleh; 2012.

7. Silvarianto, D. Faktor-faktor yang Berhubungan dengan Kejadian Dengue Shock Syndrome pada Anak dengan Demam Berdarah Dengue; 2013.

8. Tee, H. P., How, S. H., Jamalludin, A. R., Safhan, M. N. F., Sapian, M. M., Kuan, Y. C., \& Sapari, S. Risk Factors Associated with Development of Dengue; 2009.

9. Karolina Tallo, B N P Arhana, D. L., \& Utama. Kejadian perdarahan masif pada pasien DSS dihubungkan dengan jumlah leukosit, trombosit, dan kadar hematokrit. 2013; I(2), 64-73.

10. Raihan, Hadinegoro, S. R. S., \& Tumbelaka, A. R. Faktor Prognosis Terjadinya Syok pada Demam Berdarah Dengue, 2010; 12(1), 47-52.

11. WHO. Dengue Guidelines for Diagnosis, Treatment, Prevention and Control, 2009.

12. Guha-Sapir, D., \& Schimmer, B. Dengue Fever: New Paradigms for A Changing Epidemiology. Emerging Themes in Epidemiology, 2005; 2(1), 1. doi:10.1186/1742-7622-2-1.
13. U.S. Department of Health. Dengue and Dengue Hemorrhagic Fever Information for Health Care Practitioners. 2009; 1-4.

14. Moraes, G.H., Duarte,E. D. F., \& Duarte, E. C. Determinants of Mortality from Severe Dengue in Brazil: A PopulationBased Case-Control Study. American Journal of Tropical Medicine and Hygiene. 2013; 88(4):670-676.

15. Anders, K. L., Nguyet, N. M., Chau, N. V. V., Hung, N. T., Thuy, T. T., Lien, L. B., Simmons, C. P. Epidemiological Factors Associated with Dengue Shock Syndrome and Mortality in Hospitalized Dengue Patients in Ho Chi Minh City, Vietnam. The American Journal of Tropical Medicine and Hygiene 2011; 84(1):127-34.

16. Mayetti. Hubungan Gambaran Klinis dan Lab sebagai Faktor Risiko DBD. 2010; 11(5): 367-373.

17. Fahlafi, R. Hubungan Karakteristik Sosial Ekonomi Pasien Rawat Inap dengan Pemilihan Kelas Perawatan di RSUD Tangerang; 1994.

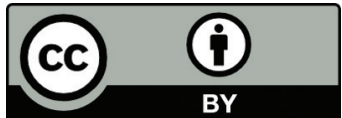

This work is licensed under a Creative Commons Attribution 